\title{
STATUS OF FRESHWATER CRAYFISH IN LATVIA
}

\author{
A. ARENS (1) AND T. TAUGBøL (2)
}

(1) Latvian Crayfish and Fish Farmers Association, Alberta 7-6, Riga LV1010, Latvia. E-mail: earens@latnet.Iv

(2) Norwegian Institute for Nature Research, Fakkelgaarden, NO-2624 Lillehammer, Norway. E-mail: trond.taugbo|@nina.no

Reçu le 29 novembre 2004

Accepté le 24 janvier 2005

Received November 29, 2004

Accepted January 24, 2005

\begin{abstract}
There are three crayfish species present in Latvia: the European noble crayfish (Astacus astacus), the narrow-clawed crayfish (Astacus leptodactylus), and the NorthAmerican signal crayfish (Pacifastacus leniusculus) species. Probably only noble crayfish are native and migrated into the country after the last glaciation. Narrow-clawed crayfish has also been present at least since the beginning of the $20^{\text {th }}$ century. In total there are current information on crayfish from 258 localities in Latvia. Most of these localities are lakes (175), but many crayfish populations are also found in river and streams (66). A few populations are found in reservoirs, ponds and gravel-pits.
\end{abstract}

The noble crayfish (Astacus astacus) is the dominant crayfish species and widely distributed in all regions of Latvia. 220 out of 258 crayfish localities contain only noble crayfish. The situation is much the same as in the 1960s, the most obvious change being that more noble crayfish populations are established in the area south of Riga. The narrowclawed crayfish has expanded its distribution since the 1960s when it was reported in 13 localities. Current records include 34 populations and eight of these are coexisting with noble crayfish. Previously, the narrow-clawed crayfish was confined to the southern part of the country. The present distribution includes several populations around Riga and in other parts of the Vidzeme region. The signal crayfish was introduced to one small lake in 1983. In 2004 it is found in another three localities (two rivers and one gravel-pit) quite a distance from the first locality. This indicates stocking by man and not a natural dispersal. Probably the signal crayfish is more widespread than the current data show.

Further in this paper, we present information on crayfish legislation, harvest and farming. The threats to the noble crayfish and the main objectives for crayfish conservation and use are also discussed.

Key-words: freshwater crayfish, distribution, conservation, exploitation.

\section{STATUT DES ÉCREVISSES EN LETTONIE}

\section{RÉSUMÉ}

Trois espèces d'écrevisses sont présentes en Lettonie ; l'écrevisse noble européenne (Astacus astacus), l'écrevisse à pattes grêles (Astacus leptodactylus) et l'écrevisse signal nord américaine (Pacifastacus leniusculus). II est probable que seule l'écrevisse noble est 
native et a migré dans le pays après la dernière glaciation. L'écrevisse à pattes grêles est aussi présente depuis au moins le début du XXe siècle. Aujourd'hui l'information fournie sur les écrevisses provient de 258 sites en Lettonie. La plupart de ces stations sont des lacs (175), mais beaucoup de populations d'écrevisses ont aussi été trouvées dans les rivières et les cours d'eau (66). Quelques populations ont été trouvées dans des réservoirs, des étangs et des gravières.

L'écrevisse noble (Astacus astacus) est l'espèce dominante la plus répandue dans toutes les régions de Lettonie. 220 sites sur 258 n'abritent que des écrevisses nobles. La situation actuelle est plus ou moins la même que celle des années 1960, l'établissement des populations d'écrevisses nobles au sud de Riga représente le changement le plus notable. L'écrevisse à pattes grêles a étendu son aire de répartition depuis les années 1960, où elle n'était répertoriée que dans 13 sites. Aujourd'hui elle est enregistrée dans 34 sites dont 8 où elle coexiste avec l'écrevisse noble. Dans le passé l'écrevisse à pattes grêles était confinée au sud du pays. La distribution actuelle inclut plusieurs populations autour de Riga et dans d'autres parties de la région de Vidzeme. L'écrevisse signal a été introduite dans un petit lac en 1983. En 2004 elle a été trouvée dans trois autres sites (deux rivières et une gravière) situés à une distance relativement importante des premiers sites. Ceci indique un repeuplement par l'Homme et non une dispersion naturelle. II est probable que l'écrevisse signal est plus répandue que ne le montrent les données actuelles.

Enfin nous présentons des informations sur la législation, la récolte et l'élevage des écrevisses. Les menaces pesant sur l'écrevisse noble et les objectifs principaux pour la conservation et l'exploitation des écrevisses sont aussi discutés.

Mot-clés : écrevisses, distribution, conservation, exploitation.

\section{INTRODUCTION}

Latvia has 12500 rivers and streams with a total length of $60000 \mathrm{~km}$ and 2256 lakes with an area of at least 1 ha making up a total area of 100000 ha, or $1.5 \%$ of the total area of the country.

Early in the $20^{\text {th }}$ century many of the Latvian rivers and lakes supported good populations of crayfish, representing a substantial economic value. In the 1920s, the Latgale region of Latvia supplied more than 20 tonnes of crayfish for the consumer market per year. The harvest was also great in other regions, but there is lacks of catch statistics.

From about 1930 onwards, the situation changed dramatically. The crayfish plague disease reached Latvia and eradicated many crayfish populations. Also physical habitat alterations, pollution and overfishing contributed greatly to the decline of crayfish populations. In the 1950s the total annual crayfish yield in Latvia was approx. 14 tonnes according to official statistics. The yield has further decreased during the last decades, and there was no official/legal crayfish catch in Latvia in the 1990s (ARENS, 1998), however, illegal catching was probably widespread.

There are three crayfish species present in Latvia (HOLDICH, 2002): the European noble crayfish (Astacus astacus), the narrow-clawed crayfish (Astacus leptodactylus), and the North-American signal crayfish (Pacifastacus leniusculus) species. Probably only noble crayfish are native and migrated into the country after the last glaciation. The noble crayfish is a threatened species according to the Bern convention, the EC's Habitat Directive and the IUCN Red List. Countries with native noble crayfish populations have a special international obligation to protect this species. In addition, the noble crayfish has a high economical, as well as ecological, social and cultural value (SWAHN, 2004; TAUGBØL, 2004), and there is a considerable interest to increase the harvest from wild and cultured populations. 
Narrow-clawed crayfish has also been present at least since the beginning of the $20^{\text {th }}$ century. Surveys undertaken in the 1960s (JURANE, 1967) concluded that noble crayfish inhabited waters all over Latvia, and narrow-clawed crayfish occurred only in the southern part with an exception for a population close to Riga. Signal crayfish was first introduced to Latvia from Lithuania in 1983 (SKURDAL et al., 1999) as part of a scientific experiment.

Due to little knowledge on the current status for freshwater crayfish in Latvia, a collaboration project between Latvia and Norway was started in 2002 aimed at producing an updated status for crayfish distribution and abundance as a basis for an action plan for crayfish management (ARENS and ARENS, 2003). The project was based on experiences from similar projects in Lithuania and Estonia (TAUGBØL, SKURDAL and BURBA, 1998, TUUSTI et al., 1998). In this paper we present data on distribution and information on current legislation, harvest and culture. We also briefly touch on the main threats to the noble crayfish in Latvia and the main objectives for crayfish conservation and use.

\section{CRAYFISH DISTRIBUTION}

Existing data (previous investigations and official statistics) have been collected and categorized, and new data have been obtained from inquiries and field investigations. In total there are current information on crayfish from 258 localities in Latvia (Table I). Most of these localities are lakes (175), but many crayfish populations are also found in river and streams (66). A few populations are found in reservoirs, ponds and gravel-pits. Populations are classified as weak, medium and good according to catch per unit effort (number of crayfish per trap night; $<0.5=$ weak, $0.5-2.5=$ medium and $>2.5=$ good) and/or an evaluation based on local knowledge.

\section{Table I}

Number of crayfish localities with the different species in the historical regions of Latvia.

\section{Tableau I}

Nombre de sites à écrevisses hébergeant différentes espèces dans les régions historiques de Lettonie.

\begin{tabular}{lccccc}
\hline & \multicolumn{5}{c}{ Crayfish species } \\
\cline { 2 - 5 } Region & $\begin{array}{c}\text { Astacus } \\
\text { astacus }\end{array}$ & $\begin{array}{c}\text { Astacus } \\
\text { leptodactylus }\end{array}$ & $\begin{array}{c}\text { Pacifastacus } \\
\text { leniusculus }\end{array}$ & $\begin{array}{c}\text { A. astacus }+\boldsymbol{A} \text {. } \\
\text { leptodactylus }\end{array}$ & Total \\
\hline Kurzeme & 74 & 0 & 0 & 0 & 74 \\
Latgale & 63 & 4 & 0 & 1 & 68 \\
Vidzeme & 59 & 10 & 4 & 5 & 76 \\
Zemgale & 24 & 12 & 0 & 2 & 40 \\
\hline Total & $\mathbf{2 2 0}$ & $\mathbf{2 6}$ & $\mathbf{4}$ & $\mathbf{8}$ & $\mathbf{2 5 8}$ \\
\hline
\end{tabular}

\section{Noble crayfish (Astacus astacus)}

The noble crayfish (Astacus astacus) is the dominant crayfish species and widely distributed in all regions of Latvia (Fig. 1). 220 out of 258 localities contain only noble crayfish. The situation is much the same as described by JURANE (1967), the most obvious change being that more noble crayfish populations are established in the area south of Riga. JURANE (1967) reported 194 noble crayfish populations whereas the current 
database contains 228 populations. Approximately $36 \%$ of the present populations are classified as medium or good and $32 \%$ as weak (Table II). For $32 \%$ of the populations there is no information on their status.

\section{Narrow-clawed crayfish (Astacus leptodactylus)}

The narrow-clawed crayfish has expanded its distribution since the 1960s when it was reported in 13 localities (JURANE, 1967). Current records include 34 populations, and eight of these are coexisting with noble crayfish (Table I). In the 1960's, no coexisting populations of noble and narrow-clawed crayfish were registered (JURANE, 1967). Approximately $18 \%$ of the narrow-clawed crayfish populations are classified as medium or good and $53 \%$ as weak. For $29 \%$ of the populations there is no information on their status. Previously, the narrow-clawed was confined to the southern part of the country (with one exception). The present distribution includes several populations around Riga and in other parts of the Vidzeme region (Fig. 1).

\section{Signal crayfish (Pacifastacus leniusculus)}

The signal crayfish was introduced to one small lake in 1983. In 2004 it was found in another three localities (two rivers and one gravel-pit) quite a distance from the first locality (Fig. 1). This indicates stocking by man and not a natural dispersal. Probably the signal crayfish is more widespread than the current data show. The signal crayfish is abundant in the lake it was introduced to, but there is no information on population status from the other three localities (Table II).

\section{LEGISLATION}

In the Latvian legislation crayfish are treated as fish. Only noble and narrow-clawed crayfish are mentioned specifically in the legislation. Signal crayfish are not mentioned.

There are two categories of fishery and crayfish catching in Latvia: commercial and amateur/recreational.

For both categories of crayfish catching apply:

- Catching can only be carried out in so-called licensed lakes, i.e. lakes that the National Board of Fisheries has decided can sustain exploitation (based on scientific advice from the Latvian Fisheries Research Institute).

- Minimum size of crayfish: $100 \mathrm{~mm}$ total length.

Figure I

Distribution of crayfish in Latvia in 2004. Each dot represents a crayfish locality. Red dots: noble crayfish; blue dots: narrow-clawed crayfish; green dots: both noble and narrow-clawed crayfish; yellow dots: signal crayfish. Yellow arrow points to the first signal crayfish locality. The boldest lines are borders between the four historical regions of Latvia. Other lines are administrative borders between districts and municipalities. Grey areas are cities.

Figure I

Distribution des écrevisses en Lettonie en 2004. Chaque point représente un site à écrevisses. Points rouges : écrevisses noble ; Points bleus : écrevisses à pattes grêles ; Points verts : écrevisses noble et à pattes grêles ; Points jaunes : écrevisses signal. La flèche jaune pointe le premier site de l'écrevisse signal. Les lignes en gras représentent les frontières entre les quatre régions historiques de la Lettonie. Les autres lignes représentent les frontières administratives entre districts et municipalités. Les villes sont représentées par des aires grises. 


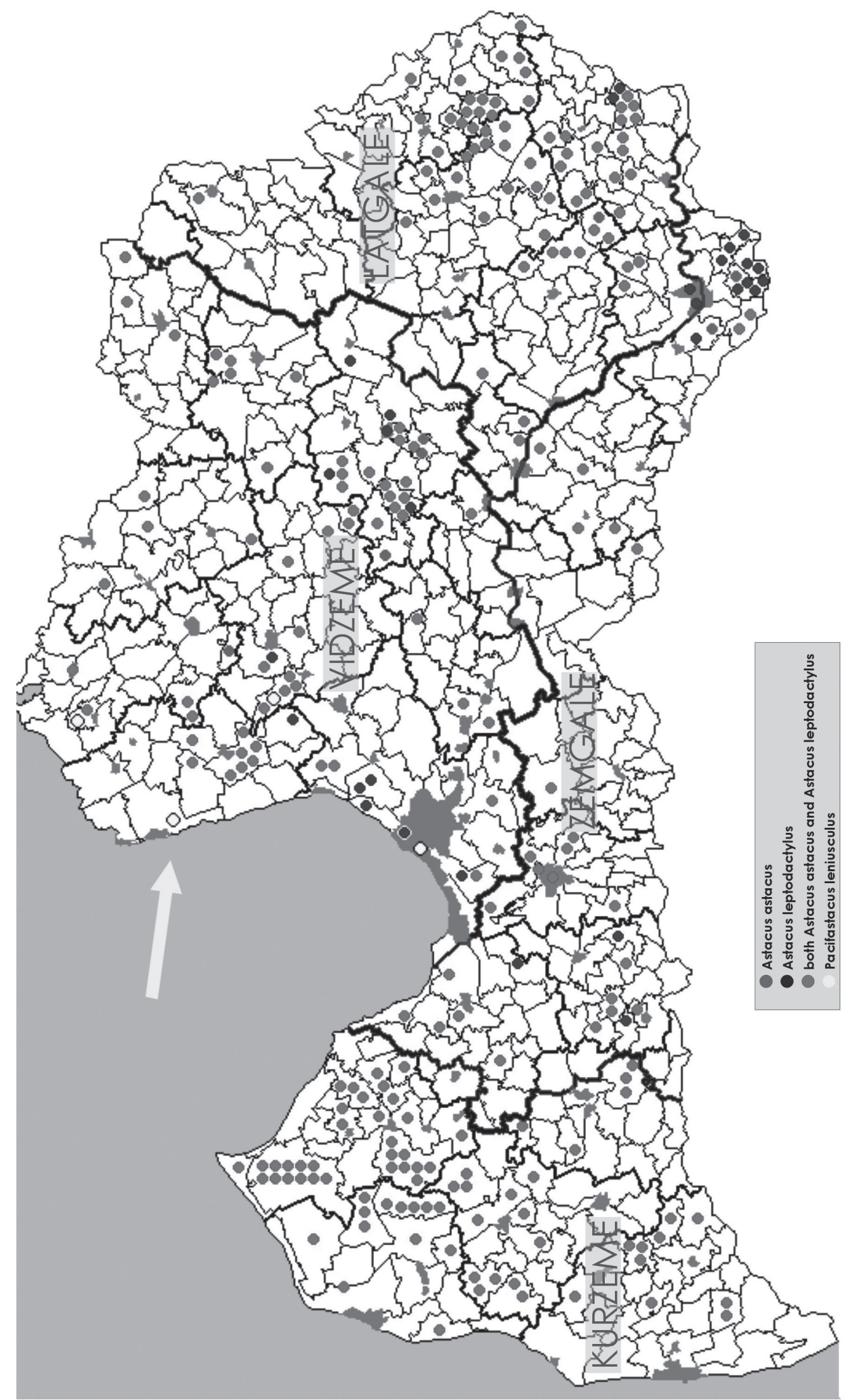




\section{Table II}

Number and proportion (in percent) of crayfish populations in different population status categories.

\section{Tableau II}

Nombre et proportion (en pourcentage) des populations d'écrevisses dans différentes catégories de statut de la population.

\begin{tabular}{lccccc}
\hline & \multicolumn{4}{c}{ Population status } & \\
\cline { 2 - 5 } \multicolumn{1}{c}{$\begin{array}{c}\text { Crayfish } \\
\text { species }\end{array}$} & $\begin{array}{c}\text { Weak } \\
\text { population }\end{array}$ & $\begin{array}{c}\text { Medium good } \\
\text { population }\end{array}$ & $\begin{array}{c}\text { Good } \\
\text { population }\end{array}$ & $\begin{array}{c}\text { No info on } \\
\text { status }\end{array}$ & Total \\
\hline $\begin{array}{l}\text { Astacus astacus } \\
\text { Astacus }\end{array}$ & $74(32 \%)$ & $36(16 \%)$ & $46(20 \%)$ & $72(32 \%)$ & 228 \\
$\begin{array}{l}\text { leptodactylus } \\
\begin{array}{l}\text { Pacifastacus } \\
\text { leniusculus }\end{array}\end{array}$ & $18(53 \%)$ & $1(3 \%)$ & $5(15 \%)$ & $10(29 \%)$ & 34 \\
\hline Total & 0 & 0 & $1(25 \%)$ & $3(75 \%)$ & 4 \\
\hline
\end{tabular}

- Catching season: July 1 September 30.

- Egg-carrying females must be released.

Specifically for commercial catching:

- A lease contract and a fishing license specifying terms for the fishery must be issued. The terms include number of traps and amount of crayfish allowed to be caught.

- The license fee varies according to the amount allowed caught.

- The by-catch of under-sized crayfish cannot constitute more than $5 \%$ of the total catch.

Specifically for amateur catching:

- A special crayfish catching license is needed. The National Board of Fisheries limits the number of licenses for each locality.

- The license specifies the period of catching (within the legal catching season), specific catching site in the water body, crayfish species and other possible regulations.

- Only dip-nets/balances and hand-catching are allowed as catching methods.

- Maximum number of dip-nets per license is 5 .

- Maximum catch per license is 50 individuals.

- License fee varies currently between 3-10 LVL (5-16 EURO).

- It is not allowed to stay at the shoreline with catching gear outside the legal catching period.

Stocking of live crayfish in natural waters needs permission from environmental authorities and a veterinary certificate stating that the stocking material is healthy.

Import of live crayfish to Latvia is allowed. Only a veterinary certificate is needed. Export of live crayfish is also allowed. The exporter must be registered with the Department of Food and Veterinary and a veterinary certificate is needed.

It is not allowed to use crayfish as bait. 


\section{CRAYFISH HARVEST AND FARMING}

For many years there has been no licensed catch of crayfish at all. Since 2002 four lakes, L. Aǵes (Limbažu district), L. Černavas (Daugavpils district), L. Kukšu (Kuldī gas district) and L. Vaidavas (Valmieras district), have been licensed for recreational/amateur catching (Fig. 2). In 2004, L. Černavas was also licensed for commercial catching. In L. Černavas and L. Aǵes the crayfish species is the narrow-clawed crayfish, in L. Kukšu the species it is the noble crayfish, and in L. Vaidavas both species occur.

The annual licensed catch is less than 1 tonne according to official statistics. However, the very restrictive license system contributes to an extensive illegal catch. Probably the total yield of crayfish in Latvia, illegal catch included, is 15-20 tonnes, indicating that in many places the conditions for crayfish have improved.

The first private crayfish farm in Latvia was started in 1994. A follow-up study conducted by the EU-PHARE program MEGAPESKA concluded that the use of modern technology and semi-intensive growing methods could make crayfish farming financially viable. The Latvian Crayfish and Fish Farmers Association (LCFFA) was founded, and plans for the establishing of Crayfish Centers and regional crayfish farms are currently being realized. The objectives of the LCFFA and the Crayfish Centers are to provide information and education on crayfish farming, and also on optimal and sustainable use and conservation of natural noble crayfish populations. Sustainable use and conservation includes the reestablishment of lost and strengthening of weak populations, and in this connection production of stocking material is of great importance.

Fig. 2 shows the location of four Crayfish Centers (three private, one state owned) and 18 privately owned crayfish farms recently established. On the map is also shown the so-called monitoring lakes. The aim of these lakes is to provide valuable information on optimal management practices. This includes knowledge on population development after stocking through regularly monitoring. An area of great current interest is also knowledge of the effects of different harvesting regimes (carried out as an experiment in selected monitoring lakes). In monitoring lakes crayfish have been stocked in 2003-2004 (blue squares in Fig. 2). In the potential monitoring lakes (blue circles in Fig. 2) no actions have yet been realized.

\section{MAIN THREATS TO THE NOBLE CRAYFISH IN LATVIA}

\section{Spread of plague-carrying North-American crayfish species}

A major threat to the native noble crayfish is the further spread of the signal crayfish already present in Latvia, and the introduction of another North American species, the spiny-cheek crayfish (Orconectes limosus) that is present in Lithuanian waters (TAUGBØL, SKURDAL and BURBA, 1998). These North American species are carriers of the crayfish plague disease that cause total mortality in noble crayfish populations. When these species are introduced to a waterbody, the crayfish plague disease will be permanently established. Noble crayfish, if present, will be exterminated and reintroduction impossible. Also further spread of the narrow-clawed crayfish may have a negative impact on the noble crayfish through competition.

\section{Pollution and habitat deterioration}

Pollution and habitat deterioration have destroyed the living conditions for crayfish and other biota in many freshwater localities. In the last century many rivers and streams lost their natural habitat, as dredging was part of the collectivisation program to provide new agriculture land. Although pollution has been reduced or ceased in many waterbodies and habitat deterioration occurs at a much lower scale, these impacts still represent a major threat. 


\section{Overfishing - insufficient management}

Overfishing is also a threat to natural crayfish populations, especially in smaller lakes and river/streams where the populations are more vulnerable to catching. Crayfish populations may withstand high exploitation levels provided the minimum size is kept (SKURDAL and TAUGBØL, 1994). The minimum size will ensure females reproduce at least once before being caught. The catching regulations and license system in Latvia are very strict, but limited public resources for control and enforcement make illegal catching widespread. Further, illegal catching and the risk for overfishing will be greater if there are no local responsibility, authority and ownership to the catching right.

\section{MAIN OBJECTIVES FOR CRAYFISH CONSERVATION AND USE}

Sustainable management of natural resources implies both conservation and exploitation. The noble crayfish is a threatened and vulnerable species according to the Bern convention, EU Habitat Directive and the IUCN Red List. Thus, Latvia has an international obligation to protect this species. Noble crayfish also have a high economical, social and cultural value (SWAHN, 2004), and there is great interest in harvesting wild and cultured populations. Such harvesting may give important additional income and contribute to local and regional development. In areas with crayfish catching traditions, the conservation and exploitation of noble crayfish are closely linked and mutually dependent (TAUGBØL and SKURDAL, 1999; TAUGBØL, 2004).

Based on these facts and the threats listed above, the main objectives for the management of natural crayfish populations in Latvia should be as follows: crayfish.

1) Prevent further spread of signal crayfish and introduction of spiny-cheek

Rationale: These crayfish species are the major threat to the noble crayfish as they carry and spread the crayfish plague. When spread to and established in waterbodies, the noble crayfish will be exterminated if present, and impossible to introduce or reestablish.

\section{2) Restoration and enhancement of noble crayfish populations.}

Rationale: Noble crayfish is a threatened species, but also very valuable from an ecological, recreational and economical point of view. Restoration and enhancement of populations will have major significance both for the conservation and for the sustainable use of the species.

\section{3) Sustainable exploitation and local involvement and responsibility.}

Rationale: The recreational and economical value of crayfish is a benefit to man. Crayfish catching may represent important additional income and play a role in regional development. Provided reasonable regulations, crayfish populations can withstand high exploitation levels. There is also a close link between exploitation and protection. Those who exploit a resource want to do it in a sustainable way provided they have some kind of ownership to the resource (or the right to exploit it). Without this provision there is no motivation for conservation.

\section{Figure 2}

Overview of the crayfish centers, crayfish farms, licensed crayfish lakes and monitoring lakes in Latvia.

\section{Figure 2}

Vue d'ensemble des centres d'écrevisses, des fermes à écrevisses, des lacs autorisés et des lacs sous surveillance en Lettonie. 


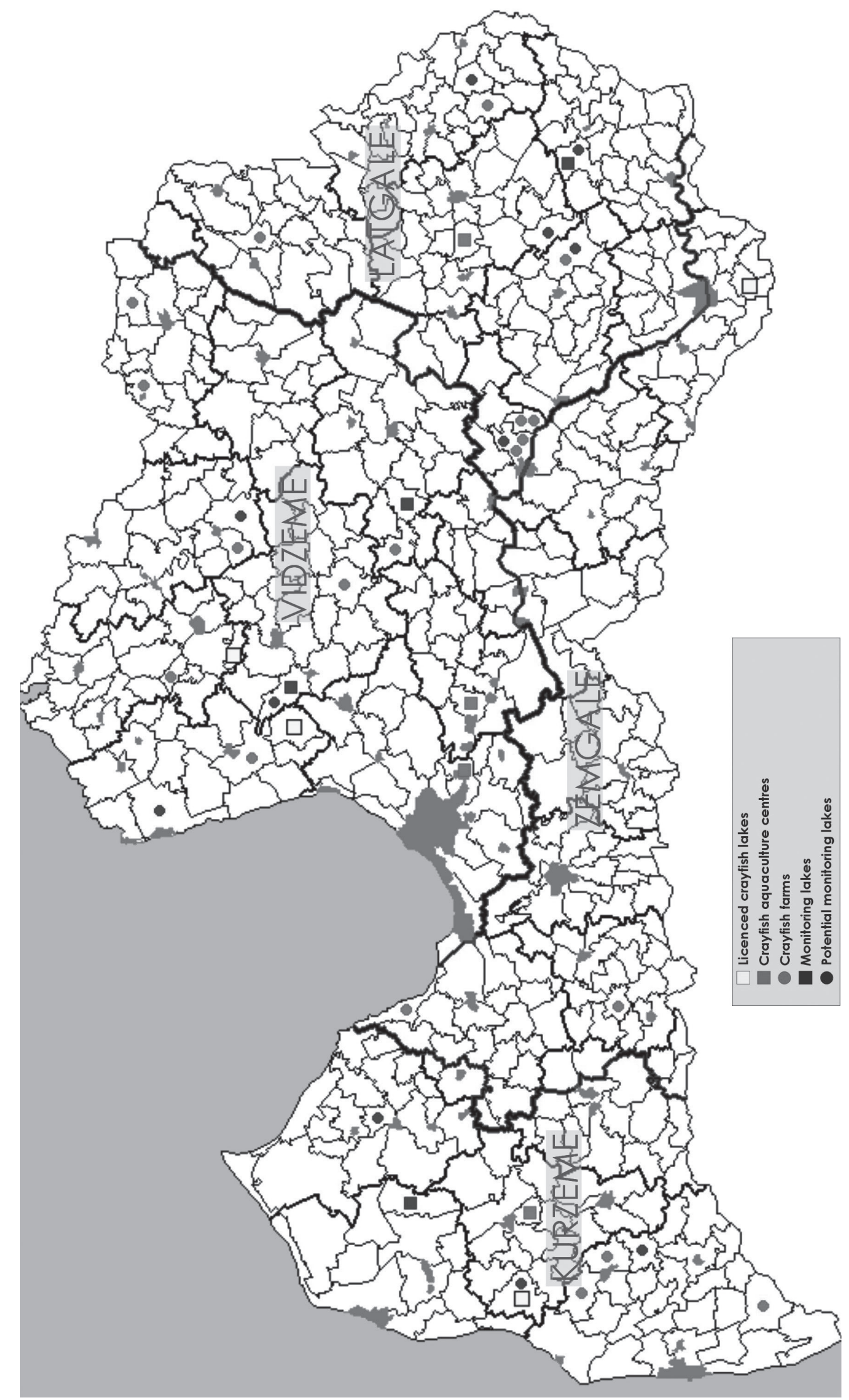


We are currently in the process of discussing actions to achieve the proposed management objectives. Recommended actions for crayfish management in Latvia will be published in the report from our collaboration project "Conservation and sustainable use of freshwater crayfish in Latvia" (TAUGBØL, ARENS and MITANS, 2004).

\section{ACKNOWLEDGEMENTS}

Many thanks to Erik ALEKSEJEV and Egils TINTE for help in collecting data, and Nils ARENS for collecting and analyzing data and producing distribution maps.

\section{REFERENCES}

ARENS A., 1998. Crayfish situation in Latvia and the Latvian crayfish program. In: TAUGBØL, T. (ed.). Report from the Nordic-Baltic workshop on crayfish research and management. Eastern Norway Research Institute and Estonian Ministry of Environment, Fishery Department. ØF-Report 26/1998.

ARENS A., ARENS N., 2003. Crayfish monitoring system aspects in Latvia. Poster presented at Craynet meeting: European native crayfish with a special focus on Astacus astacus: linking socioeconomics and conservation, Halden, Norway. Abstract Volume: 2-3.

HOLDICH D.M., 2002. Present distribution of crayfish in Europe and some adjoining countries. Bull. Fr. Pêche Piscic., 367, 611-650.

JURANE A.D., 1967. Distribution of River crayfish and its resources in water bodies of Latvian SSR. Resources of North-West inland waters. Works of Karelia department of State "HOPX". Petrozavodsk. 5, 1, 219-223 (In Russian).

SKURDAL J., TAUGBØL T., 1994. Do we need regulations for catching crayfish? Reviews in Fish Biology and Fisheries, 4, 461-485.

SKURDAL J., TAUGBØL T., BURBA A., EDSMAN L., SÖDERBÄCK B., STYRISHAVE B., TUUSTI J., WESTMAN K., 1999. Crayfish introductions in the Nordic and Baltic countries. Crustacean Issues, 11, 193-219.

SWAHN J-Ö., 2004. The cultural history of crayfish. Bull. Fr. Pêche Piscic., 372-373, 243251.

TAUGBØL T., 2004. Exploitation is a prerequisite for conservation of Astacus astacus. Bull. Fr. Pêche Piscic., 372-373, 275-279.

TAUGBØL T., SKURDAL J., BURBA A., 1998. Freshwater Crayfish in Lithuania. I: Action plan for management. II: Crayfish status report. Eastern Norway Research Institute, Report 12/1998, 83 p.

TAUGBØL T., SKURDAL J., 1999. The future of native crayfish in Europe - How to make the best of a bad situation. Crustacean Issues, 11, 271-279.

TAUGBØL T., ARENS A., MITANS A., 2004. Freshwater Crayfish in Latvia: Status and Recommendations for Conservation and Sustainable Use. Norwegian Institute for Nature Research, Latvian Crayfish and Fish Farmers Association and Latvian Fisheries Research Institute, NINA Project Report, 29, 23 p.

TUUSTI J., TAUGBØL T., SKURDAL J., KUKK L., 1998. Freshwater Crayfish in Estonia. I: Action plan for management. II: Crayfish status report. Eastern Norway Research Institute, Report 22/1998, 92 p. 